\title{
Risk and Return Portfolio of Food and Beverages Companies in Ramadhan 2019
}

\author{
Achmad Kautsar \\ Department of Management \\ Universitas Negeri Surabaya \\ Surabaya, Indonesia \\ achmadkautsar@unesa.ac.id
}

\author{
Musdholifah Musdholifah \\ Department of Management \\ Universitas Negeri Surabaya \\ Surabaya, Indonesia \\ musdholifah@unesa.ac.id
}

\author{
Nadia Asandimitra \\ Department of Management \\ Universitas Negeri Surabaya \\ Surabaya, Indonesia \\ nadiaharyono@unesa.ac.id
}

\author{
Ulil Hartono \\ Department of Management \\ Universitas Negeri Surabaya \\ Surabaya, Indonesia \\ ulilhartono@unesa.ac.id
}

\author{
Yuyum Isbanah \\ Department of Management \\ Universitas Negeri Surabaya \\ Surabaya, Indonesia \\ yuyunisbanah@unesa.ac.id
}

\author{
RA. Sista Paramita \\ Department of Management \\ Universitas Negeri Surabaya \\ Surabaya, Indonesia \\ sistaparamita@unesa.ac.id
}
Trias Madanika Kusumaningrum Department of Management
Universitas Negeri Surabaya
Surabaya, Indonesia
triaskusumaningrum@unesa.ac.id

\begin{abstract}
Ramadan Effect, one type of market anomaly, is a seasonal anomaly which shows a difference in average returns in the month of Ramadan compared to other months in one year. The phenomenon of increasing public consumption in the month of Ramadan is suspected to be a phenomenon that causes returns in Ramadan, especially in food and beverages companies different from the months outside of Ramadan. Ramadan in Indonesia has distinctive nature compared to Ramadan in other countries, namely the activity of giving each other food, so that product demand of food and beverages companies also increases. This study used the calculation of risk and returns portfolio to determine the level of risk and return portfolio of food and beverages companies during the month of Ramadan. Purposive sampling was chosen with the criteria of 3 companies that most actively moved their shares in food and beverages sector. Data analysis was explained using financial Mathematics. Based on the calculation, it was shown that PT. Indofood Sukses Makmur, Tbk (INDF) had $\mathbf{- 1 . 6 7 \%}$ of return and stocks risk at $2.67 \%$, PT. Ultrajaya Milk Industry and Trading Company, Tbk (ULTJ) had $\mathbf{- 0 . 1 9 \%}$ return and $\mathbf{0 . 3 3 \%}$ stocks risk, while PT. Siantar Top, Tbk (STTP) had 4.70\% return and stocks risk at $8.31 \%$. Calculating using portfolio calculation to minimize the risk was proven to be successful method. It showed that the individual stocks risk from the three companies could be reduced to $2.91 \%$ with positive return at $0.95 \%$.
\end{abstract}

Keywords- Ramadan effect, risk and return portfolio, food and beverages companies.

\section{INTRODUCTION}

Stock is one of the popular and dominant financial investment instruments treaded in capital market. As proof of the ownership of the company, stocks are valuable things or effects issued by the company listed in the capital market or go-public company [1]. Return is the result of an investment. Return can be in form of realized return already occurred or expected return yet to happen but is expected in the future [2]. The other side of the return is risks. Risk is one of the important factors that has to be watched out in investment analysis because every choice of investment is a risk. Risk refers to probability of profit deviation [2].

Consideration of the return and risks also accompanied by the occurrence in a company, thus investors will be convinced to invest their share. The presence of new occurrence will affect the investors in choosing which stocks will give them the amount of the profit they want. An important occurrence that contains or allegedly contains information will induce dynamics changes in the capital market and investment decisions in the future.

Ramadan effect is one of the seasonal market anomaly effects which showed that there is difference between the average return in Ramadan and other months in a year. The effect of Ramadan taken from Daily Business Recorder in Karahi Stock Exchange-100 index in Pakistan from March 1998-September 2004 found that return in Ramadan was lower and insignificant. However, there was positive and significant average return found in Syawal and Ziqad (after Ramadan). No difference was also found between returns in Ramadan with the returns in other months (one month before Ramadan and one month after Ramadan) in the Indonesia Stock Exchange [3]. Meanwhile, stocks return in Ramadan, in 14 Muslim countries in 1989-2007 had contrasting result. The return in Ramadan was 9 times higher than in other months in a year [4]. Other study on Ramadan effect anomaly concluded that sharia return stocks in Ramadan experienced increasing return one day before Eid Al-fithr [5]. In conclusion, Ramadan gave positive effect towards the trade return in sharia stocks in the stock exchange. 
The phenomenon of Ramadan effect in Indonesia causes an increase in community consumption, causing different return for food and beverages company in Ramadan. Ramadan in Indonesia has unique trait if compared to Ramadan in another country in this world. It becomes a tradition in Indonesia that people will visit their relatives in Eid Al-fithr holiday. This matter needed to be studied more to discover the abnormal return by using financial mathematics calculation system in a portfolio basis for food and beverages' superior stock listed in Indonesia Stock Exchange (IDX) in 2019.

\section{LITERATURE REVIEW}

\section{A. Risk and Return}

Return is a result that is obtained from an investment. Return can be in form of realized return already happened or expected return yet to happen but is expected in the future. Realized return is a return that has already happened. Realized return is calculated using historical data. Realized return is important because it is used as a tool to measure the performance of the company. Realized return or historical return can be also used as the basic determiner of expected return in the future [2]. The expected return is a return that the investors will get in the future. The expected return is different from a realized return; realized return is a return that has already happened, while expected return has not happened yet [2].

Calculating return only is not enough. The risk of investment needs to be considered. Return and risk are two things cannot be separated because the consideration of investment is a trade-off from these two factors. Return and risk have positive correlation; the bigger the risk, the bigger return needs to be compensated [2]. Risk can be defined as the difference between the expected return and realized a return. The higher the deviation, the higher the risk. Return and risk are two inseparable matters. Harry Markowitz stated that the decision of investment made by the investors is based on the expected return and the variety of return (as the measurement of risk). The investor is willing to get a higher risk but they need to be compensated to get a higher return too. Since Harry Markowitz proposed modern portfolio theory (1952), the risk of investment can be reduced by forming efficient portfolio, so that the risk will be lower than the risk of each investment instrument (stocks, for example) which form that portfolio. Portfolio implementation for reducing the risk is through investment diversification in that portfolio. Through choosing the right stocks and its proportion, the portfolio risk can be reduced into the minimum level [6].

\section{B. Portfolio Theory}

The portfolio is divided into two types; efficient portfolio and optimum portfolio. Efficient portfolio is portfolio which gives the biggest expected return with the same risk level or portfolio which has the lowest risk with the same expected return level [7]. We can say that portfolio is efficient if it has the same risk level, it can give a higher profit level or can produce the same profit level, but with a lower risk, meanwhile optimum portfolio is a portfolio with the combination of the best-expected return and risk. [7]
Portfolio theory was introduced through an article in the Journal of Finance and it was continued with his book in 1959 [8]. This theory is the first theory introduced for explaining level of return and risk. However, Markowitz explained risk more, especially about the investors' wants for choosing between return level and the risk. In building his theory, Markowitz gave his thoughts that investors would always choose high return level with low risk. The concept itself in a portfolio was the investors would always stand on the risk from that portfolio.

\section{Ramadhan Effect}

Ramadan effect is a kind of market anomaly namely seasonal anomaly which shows that there are differences on return averages in Ramadan if it is compared to other months in a year [8,9]. Ramadhan has become a month full of increasing things by Moslems, which capital market players expect that it increases the return so that the trading activity will be increasing too. Ramadhan effect is one of a seasonal market anomaly which shows that there are differences in return averages in Ramadhan if it is compared to another month in a year [9].

\section{METHOD}

This study used a quantitative approach because it focused on the proving of whether there was Ramadhan effect occurred in Indonesia or not. This studied was performed to food and beverages company listed in IDX on 6 May until 3 June 2019 for return and risk portfolio in Ramadhan related to stock trading activity.

In this study, every company included in the food and beverage sector was the population. Purposive sampling was used for selecting the sample by determining the sample's criteria. The stock criteria used for this study were the most traded three companies during the study period. Based on that criteria, three companies were chosen; PT. Indofood Sukses Makmur, Tbk (INDF); PT. Ultrajaya Milk Industry and Trading Company, Tbk (ULTJ); and PT. Siantar Top, Tbk (STTP). Documentation was used as the data gathering method in this study. In this study, the documentation method was in the form of historical report of stock price movements and weekly stock trading volume (every Mondays) which was gathered from Yahoo's finance.

\section{RESULT AND DISCUSSION}

At the first step, the researcher did calculation of return and risk of the stocks individually on those three companies; PT. Indofood Sukses Makmur, Tbk (INDF); PT. Ultrajaya Milk Industry and Trading Company, Tbk (ULTJ); and PT. Siantar Top, Tbk (STTP).

$$
R=\frac{P_{t}-P_{t-1}}{P_{t-1}}
$$

where,

$\mathrm{R} \quad=$ Return

$\mathrm{P}_{\mathrm{t}} \quad=$ Stock price period $\mathrm{t}$

$\mathrm{P}_{\mathrm{t}-1}=$ Stock price period $\mathrm{t}-1$ 
TABLE I. RESULT OF INDIVIDUAL STOCKS FOR EACH PERIOD

\begin{tabular}{|c|c|c|c|c|c|c|}
\hline & PRICE & \multirow{2}{*}{ RETURN } & PRICE & \multirow[b]{2}{*}{ RETURN } & PRICE & \multirow{2}{*}{ RETURN } \\
\hline & $\begin{array}{l}\text { INDF } \\
\text { (A) }\end{array}$ & & $\begin{array}{c}\text { ULTJ } \\
\text { (B) }\end{array}$ & & $\begin{array}{c}\text { STTP } \\
\text { (C) }\end{array}$ & \\
\hline $\begin{array}{|ll|}6 & \text { May } \\
2019 & \\
\end{array}$ & 6.775 & & 1.310 & & 3.200 & \\
\hline \begin{tabular}{|ll}
13 & May \\
2019 & \\
\end{tabular} & 6.400 & $-5.54 \%$ & 1.310 & $0.00 \%$ & 3.800 & $18.75 \%$ \\
\hline $\begin{array}{|lr|}20 & \text { May } \\
2019 & \\
\end{array}$ & 6.225 & $-2.73 \%$ & 1.300 & $-0.76 \%$ & 3.800 & $0.00 \%$ \\
\hline $\begin{array}{|ll|}27 & \text { May } \\
2019 & \\
\end{array}$ & 6.250 & $0.40 \%$ & 1.300 & $0.00 \%$ & 3.900 & $2.63 \%$ \\
\hline 3 Jun 2019 & 6.325 & $1.20 \%$ & 1.300 & $0.00 \%$ & 3.800 & $-2.56 \%$ \\
\hline
\end{tabular}

Based on table 1, it shows that the return of the stocks for each period in Indofood (INDF) company increased from 13 May 2019 in minus condition then on 3 June 2019 it changed into plus condition. Ultrajaya (ULTJ) tended to have stable stocks. Siantar Top's stock (STTP) showed negative trend from $18.75 \%$ to $2,56 \%$. Overall stock return was calculated based on the average of return for each period. The calculation of expected stock returns using this average method was widely used if the data return did not show clear trend pattern [2].

$$
E\left(R_{i}\right)=\frac{\sum_{t=1}^{n} R_{n}}{n}
$$

Where,

$$
\begin{array}{ll}
\mathrm{E}(\mathrm{Ri}) & =\text { Stock Expected Return } \\
\mathrm{Rn} & =\text { Return asset } i \text { on period } t \\
\mathrm{n} & =\text { Total observation on historical data }
\end{array}
$$

TABLE II. RESULT OF INDIVIDUAL STOCKS FOR EACH PERIOD

\begin{tabular}{|l|l|}
\hline Company & Return \\
\hline E(Ri) INDF (A) & $-1.67 \%$ \\
\hline E(Ri) ULTJ (B) & $-0.19 \%$ \\
\hline E(Ri) STTP (C) & $4.70 \%$ \\
\hline
\end{tabular}

The results of the calculation of individual stock returns indicated that when viewed from each stock, it turned out that each share gives a different return. Some stocks provided positive returns, while others had negative ones. Based on table 2, it shows that individual stocks return of Indofood company during Ramadhan was $-1.67 \%$. Ultrajaya company had $-0.19 \%$ individual stocks return. At the calculation of Siantar Top's individual stocks return, even though they had negative trend, their return was at $4.70 \%$. After calculating the individual return of the company, the next thing we did was calculating the risk of the individual stocks. Therefore, the portfolio needed to be formed from several shares, in this case, the portfolio was formed using 3 shares, namely INDF, ULTJ, and STTP.

$$
\text { Varians }\left(\sigma^{2}\right)=\Sigma[R-R s]^{2} \cdot p r
$$

Where,

$$
\begin{array}{ll}
\mathrm{Rs} & =\text { Return Stock } \\
\mathrm{R} & =\text { Return period }
\end{array}
$$

Pr = Probability of occurence of return-i

TABLE III. STOCK VARIANCE

\begin{tabular}{|c|c|c|c|c|}
\hline & $\begin{array}{c}\text { Probability } \\
(\mathbf{P r})\end{array}$ & $\begin{array}{c}\text { INDF } \\
\text { Variance } \\
(\mathbf{A})\end{array}$ & $\begin{array}{c}\text { ULTJ } \\
\text { Variance } \\
(\mathbf{B})\end{array}$ & $\begin{array}{c}\text { STTP } \\
\text { Variance } \\
(\mathbf{C})\end{array}$ \\
\hline 13 May 2019 & 0.25 & 0.001496 & 0.000004 & 0.019728 \\
\hline 20 May 2019 & 0.25 & 0.000114 & 0.000033 & 0.002213 \\
\hline 27 May2019 & 0.25 & 0.000428 & 0.000004 & 0.000430 \\
\hline 3 Jun 2019 & 0.25 & 0.000822 & 0.000004 & 0.005283 \\
\hline
\end{tabular}

Table 3. shows the deviation standard for measuring the absolute deviation of the values already happened with its averages (as the expected values). It can be seen from the data that the ULTJ variance was smaller than the INDF and STTP variance. This means that ULTJ shares had smaller risk compared to INDF and STTP shares. Thus, the standard deviation was still the measurement used for calculating risk. Investment composition in the four observation periods found that the variance was the square of standard deviation.

Standard Deviation Risk

$$
(\sigma)=\sqrt{\sigma^{2}}
$$

Where

$$
\sigma \quad=\text { variants }
$$

TABLE IV. INDIVIDUAL STOCKS RISK

\begin{tabular}{|l|l|}
\hline Company & Risk (o) \\
\hline INDF & $2.67 \%$ \\
\hline ULTJ & $0.33 \%$ \\
\hline STTP & $8.31 \%$ \\
\hline
\end{tabular}

Table 4 shows the result of the risk calculation of the individual stocks, where Siantar Top had the biggest risk at $8.31 \%$. The next one was Indofood, at $2.67 \%$. The last one was Ultrajaya with $0.33 \%$ risk in total.

Based on table 2 and 4, it can be concluded that this result was corresponding with investment theory, in which return and risk are two inseparable matters because the consideration of investment is a trade-off from these two factors. Return and risk have a positive relation, the higher the risk, so that the highest return that needs to be compensated [2].

$$
\begin{aligned}
& \operatorname{COV}_{\text {A.B }}= \\
& \sum_{i=1}^{n}\left[P_{n}\right] \cdot\left[\left\{R_{S A}-R_{A}\right\} \cdot\left\{R_{S B}-R_{B}\right\}\right]
\end{aligned}
$$

Where,

$\mathrm{COV}=$ Covarian

$\mathrm{R}_{\mathrm{S}} \quad=$ stocks return of $\mathrm{t}$ period

$\mathrm{R} \quad$ = overall individual stocks return 
TABLE V. COVARIANCE CALCULATING

\begin{tabular}{|c|c|c|c|c|}
\hline & $\begin{array}{c}\text { Probability } \\
\text { (Pr) }\end{array}$ & $\begin{array}{c}\text { Covarian } \\
\text { (A.B) }\end{array}$ & $\begin{array}{c}\text { Covarian } \\
\text { (A.C) }\end{array}$ & $\begin{array}{c}\text { Covarian } \\
\text { (B.C) }\end{array}$ \\
\hline 13 May 2019 & 0.25 & -0.000074 & -0.005433 & 0.000268 \\
\hline 20 May 2019 & 0.25 & 0.000061 & 0.000502 & 0.000269 \\
\hline 27 May2019 & 0.25 & 0.000039 & -0.000429 & -0.000040 \\
\hline 3 Jun 2019 & 0.25 & 0.000055 & -0.002084 & -0.000139 \\
\hline & & $\mathbf{0 . 0 0 0 0 2 0}$ & $\mathbf{- 0 . 0 0 1 8 6 1}$ & $\mathbf{0 . 0 0 0 0 9 0}$ \\
\hline
\end{tabular}

Table 5 shows covariance of each period, because the important contribution from Markowitz's portfolio model is that the risk of the portfolio cannot be calculated from the total of all the assets risk in the portfolio, but it has to be calculated from the asset risk contribution with the risk of portfolio or usually it is called as covariance. Covariance is an absolute measurement which shows how far the return of both securities in the portfolio tend to move together.

In the context of portfolio management, covariance shows how far return from both securities tends to move together. Covariance can be the form of a positive, negative figure or even zero. Covariance in this study could be assumed that Indofood with A code, Ultrajaya with B code, and Siantar Top with $\mathrm{C}$ code. The calculating of covariance can be done three times namely company $\mathrm{A}$, and $\mathrm{B}$, after that company $\mathrm{A}$ and $\mathrm{C}$, and the last company $\mathrm{B}$ and $\mathrm{C}$.

$$
\sigma_{\text {POKT }}=\sqrt{\left[\begin{array}{c}
{\left[\left(W_{A}\right)^{2} \cdot\left(\sigma_{A}\right)^{2}\right]+\left[\left(W_{B}\right)^{2} \cdot\left(\sigma_{B}\right)^{2}\right]+} \\
{\left[\left(W_{C}\right)^{2} \cdot\left(\sigma_{C}\right)^{2}\right]+} \\
{\left[2, W_{A}, W_{B}, \rho_{A B} \cdot \sigma_{A}, \sigma_{B}\right]+\left[2, W_{A}, W_{C}, \rho_{A C}, \sigma_{A}, \sigma_{C}\right]} \\
+\left[2, W_{B}, W_{C}, \rho_{B C} \cdot \sigma_{B}, \sigma_{C}\right]
\end{array}\right.}
$$

$$
\begin{aligned}
& \text { Where, } \\
& \sigma_{\text {PORT }}=\text { Portfolio risk } \\
& \mathrm{W} \quad \text { = weight } \\
& \sigma \quad=\text { individual stocks risk } \\
& \rho \quad=\text { Covariant }
\end{aligned}
$$

This sixth equity shows how to calculate portfolio which the weight of each stock was $33.33 \%$ so that the risk for the portfolio was $2.91 \%$. The portfolio return was the average of the three stocks return with the result of the calculation at $0.95 \%$

\section{CONCLUSION}

Based on the calculation result by using financial mathematics shows that PT. Indofood Sukses Makmur, Tbk (INDF) had $-1.67 \%$ of return which means that Indofood during Ramadhan 2019 experienced stock price reduction with stocks risk at $2.67 \%$. PT. Ultrajaya Milk Industry and Trading Company, Tbk (ULTJ) had $-0.19 \%$ return. It means that Ultrajaya's stocks during Ramadhan 2019 experienced stock's price reduction, but it was better than Indofood, at $0.33 \%$ stocks risk. The last one is PT. Siantar Top, Tbk (STTP) which had $4.70 \%$ return, meaning that Siantar Top's stocks price in Ramadhan 2019 was increased compared to both former companies with risk of stock at $8.31 \%$.

The results proved that the higher the return, the higher the risk. From those three return stocks, the lowest return was owned by Indofood with $-1.67 \%$ and $2.67 \%$ for the risk. The next one which gave positive risk was Siantar Top with $4.70 \%$, and highest risk at $8.31 \%$. Calculation using portfolio calculation to minimize risk was proven to be successful method. On the equation 6 , it showed that the risk of the individual stocks from the three companies could be reduced to $2.91 \%$ with positive return at $0.95 \%$.

Based on the Ramadhan effect, phenomena which would be allegedly resulting in the excessive demand for food and beverage companies was not proven. The result showed that two from three companies had negative return. This result happened because the investors gave slow response to the chance of excessive demand for food and beverages during Ramadhan, thus demand for stocks was not high. Furthermore, the result of this study proved that portfolio stocks purchasing was more efficient than purchasing individual stocks.

The limitation of this study lies in the total amount of companies observed, which were three companies. The writer hopes that there will be more companies to be observed on the next studies. Other than that, this study only focuses on food and beverages companies. It can be developed in other sectors listed on IDX.

\section{ACKNOWLEDGMENT}

Our gratitude goes to the Rector of Universitas Negeri Surabaya, Dean of the Faculty of Economics and Business, and the team in Department of Management.

\section{REFERENCES}

[1]. A. Halim, Analisis Investasi, Jakarta: Salemba Empat, 2005.

[2]. J. Hartono, Metodologi Penelitian Bisnis, 6th ed., Yogyakarta: BPFE, 2010.

[3]. D. Safitri, and N. Asandimitra, "Analysis of The Ramadan Effect in Indonesia Stock Exchange,” Indian J. Financ., vol. 10, no. 8, pp. 55$65,2016$.

[4]. J. Białkowski, A. Etebari, and T. P. Wisniewski, "Fast profits: Investor sentiment and stock returns during Ramadan,” J. Bank. Financ., vol. 36, no. 3, pp. 835-845, 2012.

[5]. E. Girard, and M. Omran, "On the relationship between trading volume and stock price volatility in CASE," Int. J. Manag. Fin., vol. 5, no. 1, pp. 110-134, 2009.

[6]. Z. Zubir, Manajemen Portofolio Penerapan Dalam Investasi Saham, Jakarta: Salemba Empat, 2011.

[7]. Jogiyanto, Teori Portofolio dan Analisis Investasi, 10th ed., Yogyakarta: BPFE, 2015.

[8]. S. A'immah, Suhandak, and R. R. Hidayat, "Reaksi Abnormal Return dan Tranding Volume Activity Terhadap Ramadhan Effect (Studi pada Perusahaan Food and Beverages yang Terdaftar di Bursa Efek Indonesia Periode 2013-2014)," Jurnal Administrasi Bisnis, vol. 27, no. 1, pp. 1-10, 2015.

[9]. H. Akrami, M. Garkaz, and Mehrazin, "The Effect Of Ramadhan Month On Stock Abnormal Return Of The Companies Accepted In Tehran Stock Exchange," Eco. Financ. Rev., vol. 2, no. 5, pp. 45-51, 2012.

[10]. H. Markowitz, "Portfolio Selection," The Journal of Finance, vol. 7, no. 1 , pp. 77-91, 1959 .

[11]. K. Mustafa, "The Islamic Calendar Effect in Karachi Stock Market," Int. Business Research Conf. Dubai UAE, pp. 562-574, 2008. 